\title{
Survival and growth of
}

\section{Jacaratia mexicana seedlings inoculated with arbuscular mycorrhizal fungi in a tropical dry forest}

\section{Supervivencia y crecimiento de plántulas de Jacaratia mexicana inoculadas con hongos micorrícico arbusculares dentro de un bosque tropical seco}

\author{
Ramón Zulueta-Rodríguez', Luis G. Hernandez-Montiel2*, Bernardo Murillo-Amador², \\ Miguel V. Córdoba-Matson² y Liliana Lara' and Isabel Alemán Chávez'
}

1 Facultad de Ciencias Agrícolas. Universidad Veracruzana. Xalapa, Veracruz, México.

\author{
2 Centro de Investigaciones Biológicas del Noroeste. * Corresponding author: Ihernandez@cibnor.mx
} La Paz, Baja California Sur, México.

\begin{abstract}
Jacaratia mexicana is not only an endemic and typical tropical dry forest tree of Mexico, it is considered as a direct ancestor of the papayo (Carica papaya). Locally it is mainly used in traditional medicine, for human food or for feeding backyard animals (forage plant), but its use value is very restricted or even unknown. Nevertheless, various abiotic and anthropogenic pressures in its Mexican habitat are causing populations of this tree to decline alarmingly. Arbuscular mycorrhizal fungi (AMF) are microorganisms that have an important role for the regeneration of tree species by increasing their ability to absorb water and nutrients. The aim of this study was to determine the effect of AMF on growth and survival of seedlings of J. mexicana transplanted within a fragmented area of the remaining dry forest located in the central portion of the state of Veracruz. We measured height, stem diameter, number of leaves, percent seedling survival and mycorrhizal colonization. Results showed increases in all growth-related variables when seedlings were inoculated with AMF. The results suggest that micosymbionts can play a critical role for the regeneration of J. mexicana and possibly other species of tree within the dry forest, especially helping this endemic species that is currently surviving in a fragmented environment under unfavorable conditions of low availability of water and nutrients.
\end{abstract}

KEYWORDS: endangered ecosystem, endemic tree, regeneration of species, tropical dry forest, Veracruz.

\section{RESUMEN}

Jacaratia mexicana no es solo un árbol endémico y típico de los bosques tropicales secos de México, sino que se le considera como ancestro evolutivo del papayo (Carica papaya). Se le aprecia en la medicina tradicional, para alimentación del ser humano o cría de animales de traspatio (planta forrajera), pero su valor de uso es muy restringido o incluso desconocido. Sin embargo, presiones abióticas y antropogénicas de su hábitat natural están causando una alarmante reducción de las poblaciones naturales de esta Caricaceae. Los hongos micorrízicos arbusculares (HMA) son microorganismos que juegan un papel importante en la regeneración de especies debido al aumento de su capacidad para absorber agua y nutrientes. El objetivo de este estudio fue determinar el efecto de los HMA sobre el crecimiento y supervivencia de plántulas de J. mexicana trasplantadas dentro de un área fragmentada del bosque tropical seco ubicado en la parte central del estado de Veracruz. Se determinó en este estudio la altura, diámetro, número de hojas, porcentaje de supervivencia y colonización micorrízica. Los resultados muestran incrementos en todas las variables relacionadas con el crecimiento cuando las plántulas fueron inoculadas con HMA. Los resultados sugieren que estos micosimbiontes pueden desempeñar un papel fundamental para el establecimiento de árboles como J. mexicana y posiblemente de otros componentes dentro del bosque tropical seco, los cuales actualmente sobreviven en un entorno fragmentado y bajo condiciones desfavorables de baja disponibilidad de agua y nutrientes.

Palabras Clave: ecosistema en peligro, árbol endémico, regeneración de especies, bosque tropical seco, Veracruz. 


\section{INTRODUCTION}

Jacaratia mexicana is an endemic tree of Mexico that is representative of species living in the tropical dry forest (Arias et al., 2012). Its geographical distribution comprises southern and central México (states of Campeche, Chiapas, Colima, Guerrero, Michoacán, Morelos, Oaxaca, Yucatán and Veracruz); in Central America it can be found in Nicaragua and El Salvador (Moreno, 1980; Hernández-Alvarez et al., 2006). In the state of Veracruz the tree can be located in Misantla, Alvarado and near the port of Veracruz (Lascurain et al., 2010). The tree is very popular and is well known and belongs to the Caricaceae family (Ramos-Martínez et al., 2012). It is used locally for food and is also used medicinally, for feeding backyard animals (forage plant), firewood (fuel for cooking), as well as having pharmaceutical and agroindustrial uses (Zulueta, 2003). Nowadays, its silvopastoral potentiality is recognized (Flores and Bautista, 2012). Despite its many and countless utilitarian qualities, populations of $J$. mexicana are at risk because of constant human pressures which unfortunately are accelerating the destruction of vast areas of tropical dry forest (Trejo and Dirzo, 2000) putting at risk the natural populations of this tree (Moreno-Casasola and Paradowska, 2009). Furthermore, the climatic and soil factors prevailing within the tropical dry forest restrict the growth and survival of the tree, mainly because of a decrease in water and nutrient availability, causing its natural regeneration rate to be low. Its loss contributes to the loss of ecosystem services that affect vegetation establishment including the deterioration of ground quality or erosion as well as soil macro components (Meave et al., 2012).

Arbuscular mycorrhizal fungi (AMF) are organisms that have a very important role in the functionality and composition of plant communities. AMF already have been used successfully in the regeneration of some tree species of the dry tropics (Zulueta, 2003; Huante et al., 2012). In Mexico, they have been recorded in all ecosystems, from coniferous forests, hills, sand coastlines, to very humid environments like rainforests, as well as present in arid environments such as deserts and tropical dry forests.
Among the main functions of AMF in plants is to increase absorption of water and nutrients, especially those elements limiting plant growth such as phosphorus, sodium, boron, copper, zinc, potassium, iron, magnesium and calcium (Cardoso and Kuyper, 2006; Meding and Zasoski, 2008; Watts-Williams and Cavagnaro, 2014). AMF in plants also have an important role protecting plants against attack of soil pathogens, as well as improving tolerance to drought, heavy metals and also reducing damage caused by salinity (Jung et al., 2012; Porcel et al., 2012; Wilson et al., 2012).

\section{OBJECTIVES}

There are few records of the effect of AMF in the regeneration of forest species in the tropical dry forest, thus the objective of the present study was to analyze the effects of mycorrhiza formation in J. mexicana seedlings on survival and growth of this specie in its natural habitat.

\section{MATERIALS AND METHODS}

\section{Study site}

The study was conducted within a fragment of tropical dry forest located in an area called La Bandera (19 $27^{\prime} 50^{\prime \prime}$ $\mathrm{N}$ and $\left.96^{\circ} 33^{\prime} 12 " \mathrm{~W}\right)$ in the municipality of Actopan, Veracruz, Mexico, owned by the Facultad de Ciencias Agrícolas de la Universidad Veracruzana, Campus Xalapa (FCA-UV). There, a humid tropical climate prevails $\left(\mathrm{Aw}_{\mathrm{o}}[\mathrm{w}]\right.$ [i']gw") with an average annual temperature of $24.8^{\circ} \mathrm{C}$ and rainfall of around $900 \mathrm{~mm}$ a year. The soil type of the study area is a rendzic leptosol, clayey, stony, excessively drained and shallow, containing $8.56 \%$ organic matter, low phosphorus $\left(6.78 \mathrm{ppm}^{1}\right)$, potassium (0.56 ppm), sodium (1 ppm) and high calcium (60 ppm) and magnesium (5.6 ppm) (Castañeda, 2000).

\section{Mycorrhizal fungi inoculum}

The AMF inoculum was provided by the Laboratorio de Organismos Beneficos of the FCA-UV and consisted of

\footnotetext{
I Soil available P in the study area was determined according to Olsen method suggested by SARH (1978).
} 
Acaulospora morrowiae, A. scrobiculata, A. spinosa, Claroideoglomus etunicatum, Funneliformis mosseae, F. geosporus, Gigaspora rosea, Gi. decipiens, Glomus aggregatum, G. macrocarpum, G. intraradices and Scutellospora pellucida.

\section{Seed collection}

Within the study area, fruits were collected of wild specimens of J. mexicana. The seeds collected from the fruits were washed with sterile distilled water to remove the sarcotest then allowed to dry for 7 days on sterile paper towels under shade at room temperature. Seeds were disinfected with sodium hypochlorite at $10 \%$ for $15 \mathrm{~min}$, rinsed with sterile distilled water and placed in containers of high density polyethylene $(35 \mathrm{~cm} \times 48.5 \mathrm{~cm} \times 13.5 \mathrm{~cm})$ with perforations in the base for drainage and aeration. The containers were then maintained in an incubator at low temperature $\left(20^{\circ} \mathrm{C}\right)$ and constant humidity until seedling emergence.

\section{Preparation of the substrate}

A substrate containing a mixture of soil, sand and tepezil ${ }^{2}$ 3:1.5:3 (v/v) was autoclaved for $1 \mathrm{~h}$ at $120{ }^{\circ} \mathrm{C}$ and then aired for 3 consecutive days. We filled black plastic bags of $10 \mathrm{~cm} \times 20 \mathrm{~cm}$ and containers of high density polyethylene $(35 \mathrm{~cm} \times 48.5 \mathrm{~cm} \times 13.5 \mathrm{~cm})$ with the mixture.

\section{Plant culture and mycorrhizal inoculation}

Once the seedlings had their first pair of true leaves and a height of $4 \mathrm{~cm}$, they were planted one per container above $6 \mathrm{~g}$ of AMF root inoculum. The bags remained for fifteen days in the nursery of the FCA-UV, and then were subsequently transplanted with a $30 \mathrm{~cm}$ distance between seedlings and furrows. The distance is long enough so that the roots of each seedling did not intermingle during the treatment period. In addition, the experiment was performed within the tropical dry forest during the dry season, therefore the seedlings root growth is limited because of water scarcity. Fortnightly, height, stem diameter, leaf

2 Tepezil is a sandy-like inert mineral of fine grain, light weight and low cost. number, and survival percentage were quantified, and at the end of the experiment ( 75 days after inoculation, DAI) the percentage of mycorrhizal colonization was determined. Fifteen seedlings of J. mexicana were used for each treatment and the experiment was repeated twice.

\section{Mycorrhizal colonization}

At 75 DAI the extracted roots of five plants from the field were fixed in FAA (formalin: acetic acid: alcohol) and were stained using the method proposed by Phillips and Hayman (1970). Subsequently, the percentage of mycorrhizal colonization was determined following the grid-line intersection method described by Giovannetti and Mosse (1980).

\section{Micrographs from scanning electron microscope}

To observe the mycorrhizal colonization of J. Mexicana, samples of roots were washed with saline solution and fixed by immersion in $2.5 \%$ glutaraldehyde in phosphate buffer at $\mathrm{pH} 7.4$ for $2 \mathrm{~h}$ at $4{ }^{\circ} \mathrm{C}$. The preparation methodology of Prasad et al. (2013) was used, and the specimens were observed under a scanning electron microscope (Hitachi S-3000N, San Jose, CA, USA).

\section{Statistical analysis}

We used the statistical package Statistica v. 10.0 for Windows (StatSoft, 2011). For analysis of data a one-way repeated measures ANOVA result was used for comparison of means of each variable tested since there were only two treatments compared at a time (at a significance level $\mathrm{P}<$ $0.05)$.

\section{RESULTS AND DISCUSSION}

We observed a positive effect on growth and survival for the plants of $J$. mexicana inoculated with AMF. In terms of height, AMF plants showed an increase of $56.92 \%$ compared to plants that were not inoculated; while in stem diameter and number of leaves, AMF plants showed an increase of $123.24 \%$ and $102.56 \%$, respectively, compared to the treatment without the microorganisms (Table 1). Of the total seedlings of $J$. mexicana transplanted into 
the tropical dry forest, survival with AMF was $78.58 \%$, and without AMF it was $54.29 \%$ at 75 DAI.

The percentage of root colonization was determined to be $53.33 \%$, while in the roots of non-inoculated seedlings; there was no evidence of AMF (Fig. 1). The effect of promoting the growth of AMF to J. mexicana is related primarily to an increase in nutrient absorption and water, which are essential for plants that live within the tropical dry forest (Gehring, 2003; Grilli et al., 2013). Zulueta (2003) determined that J. mexicana is a species capable of associating with AMF, which may increase its growth under controlled conditions. The association between plants of $J$. mexicana and AMF was instrumental in increasing survival in the field. AMF can alter water movement in host plants and can modify the morphology of root systems (Sharma and Yadav, 2013), allowing plants to tolerate environments where there is limited availability of water and nutrients (Gerhardt, 1998; Pringle et al., 2011).

AMF plays a fundamental role for the regeneration of different tree species that compose dry forests and other habitats (Ceccon and Hernández, 2009; Gómez-Romero et al., 2013). J. mexicana is a species of which the potential for conservation tends to decrease with the relentless destruction of its habitat. The search for alternatives for propagation and improvement of physiological processes aimed at increasing the survival of this species, which naturally has very low rate regeneration, makes the improvement of growth by AMF important in the conservation of this Mexican tree species (Zulueta et al., 2010). J. mexicana seedlings that were not inoculated with AMF showed increased mortality and decreased development mainly because of severe water stress that predominated in the study area as is typical of tropical dry forest. Seedlings without AMF have limited ability to absorb water (Tian et al., 2013) and nutrients (primarily phosphorus) which are limiting factors for plant growth (Esmaeilifar, 2013).

AMF colonization of the roots of seedlings $J$. mexicana was important for their growth and survival. The soil moisture content is a key factor in AMF development and accordingly, their chances for effecting root colonization (Huang et al., 2011). While there are studies that relate the role of mycorrhizal symbiosis and survival strategies deployed by various tree species under conditions of

TABLE 1. Growth variables of Jacaratia mexicana with and without arbuscular mycorrhizal fungi (AMF) in the tropical dry forest.

\begin{tabular}{|c|c|c|c|c|c|}
\hline \multirow{2}{*}{ Treatment } & \multicolumn{5}{|c|}{$\mathrm{DAI}{ }^{*}$} \\
\hline & 15 & 30 & 45 & 60 & 75 \\
\hline & \multicolumn{5}{|c|}{ Foliage height (cm) } \\
\hline $\mathrm{Jm}^{\alpha}$ & $5.58 \pm 0.34 a^{*}$ & $6.34 \pm 0.27 a$ & $6.41 \pm 0.82 a$ & $6.68 \pm 0.74 a$ & $7.29 \pm 0.95 a$ \\
\hline$J \mathrm{~m}+\mathrm{AMF}^{\beta}$ & $5.54 \pm 0.32 a$ & $6.58 \pm 0.30 a$ & $8.46 \pm 0.75 b$ & $10.01 \pm 0.91 b$ & $11.44 \pm 0.85 b$ \\
\hline \multicolumn{6}{|c|}{ Diameter (mm) } \\
\hline $\mathrm{Jm}$ & $2.21 \pm 0.41 a$ & $2.81 \pm 0.44 a$ & $2.89 \pm 0.64 a$ & $3.56 \pm 0.80 a$ & $4.08 \pm 0.82 a$ \\
\hline$J \mathrm{~m}+\mathrm{AMF}$ & $2.28 \pm 0.42 a$ & $2.91 \pm 0.38 a$ & $3.98 \pm 0.34 b$ & $4.51 \pm 0.91 \mathrm{~b}$ & $5.64 \pm 0.62 b$ \\
\hline \multicolumn{6}{|c|}{ Number of leaves } \\
\hline $\mathrm{Jm}$ & $2.2 \pm 0.59 a$ & $2.5 \pm 0.71 a$ & $3.1 \pm 0.74 a$ & $3.5 \pm 0.71 a$ & $3.9 \pm 0.84 a$ \\
\hline $\mathrm{Jm}+\mathrm{AMF}$ & $2.2 \pm 0.52 a$ & $2.4 \pm 0.65 a$ & $3.5 \pm 0.52 a$ & $4.8 \pm 0.42 b$ & $5.4 \pm 0.87 b$ \\
\hline
\end{tabular}

*DAl days after inoculation with AMF (Arbuscular Mycorrhizal Fungi)

$\propto$ J. mexicana (Jm) plants not inoculated with AMF

$\beta$ J. mexicana (Jm) plants inoculated with AMF prior to transplant to the field

${ }^{*}$ Mean values followed by the same letter in the same column are not significantly different $(P>0.05)$ 


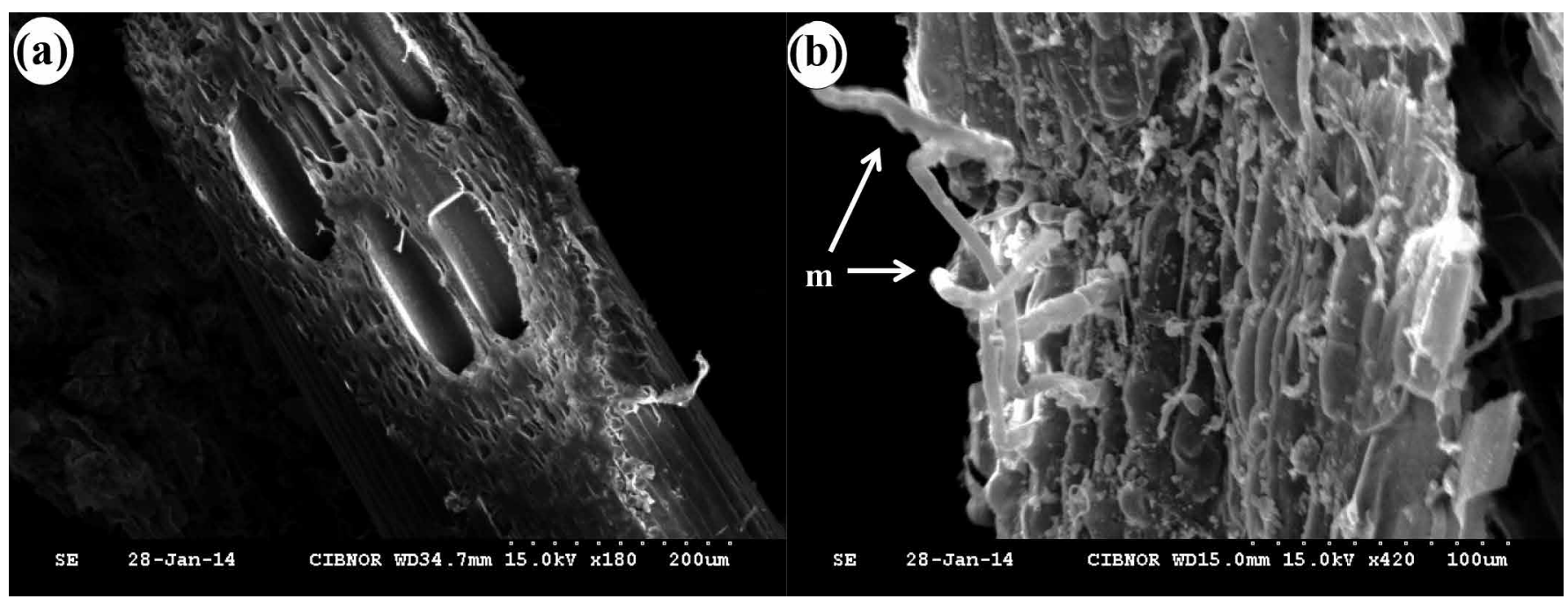

FIGURE 1. Scanning electron microscopy of Jacaratia mexicana seedlings roots. (a) Root of J. mexicana without arbuscular mycorrhizal fungi (AMF) and, (b) with AMF, $\mathrm{m}=$ mycelium.

severe water stress (Sudova, 2009; Grilli et al., 2012), at present there are few studies conducted in tropical dry forest with AMF in Mexico. The seedlings of J. mexicana without AMF that were transplanted into field showed no colonization by native AMF as commonly observed in these studies (Allen et al., 2005). The dry season that prevailed throughout the experiment in the tropical dry forest (unusual in this area in the study year) had an influence on the ability to colonize the native AMF to J. mexicana plants. Studies have found that the activity, survival and life cycle of the AMF is influenced by soil moisture (Anderson et al., 1984; Camargo-Ricalde and Esperón-Rodríguez, 2005). The lack of water in dry seasons significantly decreases the capacity of the AMF to colonize the roots of host plants (Moreira-Souza et al., 2003; Guadarrama et al., 2014).

\section{CONCLUSIONS}

J. mexicana is tree that is considered to be the direct ancestor of the papaya tree. Populations of the tree are presently at risk of disappearing from its native habitat. This ancestral tree has been used historically by local populations for wood and medicinally. We found that seedlings pre-inoculated with AMF had improved survival after transplant to a dry forest site. In addition, our results show increases in all growth related variables with AMF inoculation. These results suggest that micosymbionts play a critical role in the regeneration of tree species within the dry forest, at least for J. mexicana.

\section{REFERENCES}

Allen, M.F., E.B. Allen and A., Gómez-Pompa. 2005. Effects of mycorrhizae and nontargetorganisms on restoration of a seasonal tropical forest in Quintana Roo, Mexico: factors limiting tree establishment. Restoration Ecology 13(2):325-333.

Anderson, R.C., A.E. Liberta and L.A. Dickman. 1984. Interaction of vascular plants and vesicular-arbuscular mycorrhizal fungi across a soil moisture-nutrient gradient. Oecologia 64:111-117.

Arias, D.M., A.L. Albarrán-Lara, A. González-Rodríguez, J. Peñaloza-Ramírez, O. Dorado and E. Leyva. 2012. Genetic diversity and structure of wild populations of the tropical dry forest tree Jacaratia Mexicana (Brassicales: Caricaceae) at a local scale in Mexico. Revista de Biología Tropical 60(1):1-10.

Camargo-Ricalde, S.L. y M. Esperón-Rodríguez. 2005. Efecto de la heterogeneidad espacial y estacional del suelo sobre 
la abundancia de esporas de hongos micorrizógenos arbusculares en el valle semiárido de Tehuacán-Cuicatlán, México. Revista de Biología Tropical 53(3-4):339352.

Cardoso, I.M. and T.W. Kuyper. 2006. Mycorrhizas and tropical soil fertility. Agriculture Ecosystem and Environment 116(1-2):72-84.

Castañeda, A.M. 2000. Cartografía detallada de suelos del campo experimental La Bandera, municipio de Actopan, Veracruz. Thesis, Universidad Veracruzana, Facultad de Ciencias Agrícolas, Campus Xalapa, Veracruz, México. $110 \mathrm{p}$.

Ceccon, E. and P. Hernández. 2009. Seed rain dynamics following disturbance exclusion in a secondary tropical dry forest in Morelos, Mexico. Revista de Biología Tropical 57(1-2):257-269.

Esmaeilifar, A. 2013. Influence of irrigation, phosphorus and mycorrhiza on date palm. Advances in Environmental Biology 7(1):123-130.

Flores, J.S. and F. Bautista. 2012. Knowledge of the Yucatec Maya in seasonal tropical forest management: The forage plants. Revista Mexicana de Biodiversidad 83(2):503518.

Gerhardt, K. 1998. Leaf defoliation of tropical dry forest tree seedlings-implications for survival and growth. Trees 13(2):88-95.

Gehring, C.A. 2003. Growth responses to arbuscular mycorrhizae by rain forest seedlings vary with light intensity and tree species. Plant Ecology 167(1):127-139.

Giovannetti, M. and B. Mosse. 1980. An evaluation of techniques for measuring vesicular arbuscular mycorrhizal infection in roots. New Phytology 84(3):489-500.

Gómez-Romero, M., J. Villegas, C. Sáenz-Romero and R. Lindig-Cisneros. 2013. Efecto de la micorrización en el establecimiento de Pinus pseudostrobus en cárcavas. Madera y Bosques 19(3):51-63.

Grilli, G., C. Urcelay and L. Galetto. 2012. Forest fragment size and nutrient availability: complex responses of mycorrhizal fungi in native-exotic hosts. Plant Ecology 213(1):155165.
Grilli, G., C. Urcelay and L. Galetto. 2013. Linking mycorrhizal fungi and soil nutrients to vegetative and reproductive ruderal plant development in a fragmented forest at central Argentina. Forest Ecology and Management 310:442-449.

Guadarrama, P., S. Castillo, J.A. Ramos-Zapata, L.V. Hernández-Cuevas and S.L. Camargo-Ricalde. 2014. Arbuscular mycorrhizal fungal communities in changing environments: The effects of seasonality and anthropogenic disturbance in a seasonal dry forest. Pedobiologia 57:87-95.

Hernández-Álvarez, A., D.R. Pelz and F.C. Rodríguez. 2006. Inventorying and monitoring of tropical dry forests tree diversity in Jalisco, Mexico using a geographical information system. In: C. Aguirre-Bravo, P.J. Pellicane, D.P. Burns y S. Draggan, eds. Monitoring Science and Technology Symposium: Unifying Knowledge for Sustainability in the Western Hemisphere. U.S. Department of Agriculture, Forest Service, Rocky Mountain Research Station. Denver, CO. p:638-648.

Huang, Z., Z.R. Zou, C.X. He, Z.Q. He, Z.B. Zhang and J.M. Li. 2011. Physiological and photosynthetic responses of melon (Cucumis melo L.) seedlings to three Glomus species under water deficit. Plant Soil 339(1-2):391-399.

Huante, P., E. Ceccon, A.S. Orozco, M.E.C. Sánchez, I. Acosta and E. Rincón. 2012. The role of arbuscular mycorrhizal fungi on the early-stage restoration of seasonally dry tropical forest in Chamela, Mexico. Revista Árvore 36(2):279_ 289.

Jung, S.C., A. Martinez-Medina, J.A. Lopez-Raez and M.J. Pozo. 2012. Mycorrhiza-induced resistance and priming of plant defenses. Journal of Chemical Ecology 38(6):651664.

Lascurain, M., S. Avendaño, S. del Amo and A. Niembro. 2010. Guía de frutos silvestres comestibles en Veracruz. Fondo Sectorial para la Investigación, el Desarrollo y la Innovación Tecnológica Forestal. Conafor-Conacyt. México. $144 \mathrm{p}$.

Meave, J.A., M.A.R. Romero, S.H.M. Salas, E.A.G. Perez and J.A.C. Gallardo. 2012. Diversidad, amenazas y oportunidades para la conservación del bosque tropical caducifo- 
lio en el estado de Oaxaca, México. Ecosistemas 21(1-2):85-100.

Meding, S.M. and R.J. Zasoski. 2008. Hyphal-mediated transfer of nitrate, arsenic, cesium, rubidium, and strontium between arbuscular mycorrhizal forbs and grasses from a California oak woodland. Soil Biology and Biochemistry $40(1): 126-134$.

Moreira-Souza, M., S.F. Trufem, S.M. Gomes-Da-Costa and E.J. Cardoso. 2003. Arbuscular mycorrhizal fungi associated with Araucaria angustifolia (Bert.) O. Ktze. Mycorrhizal 13(4):211-215.

Moreno, N.P. 1980. Caricaceae. Flora de Veracruz 10:11-17.

Moreno-Casasola, P. and K. Paradowska. 2009. Especies útiles de la selva baja caducifolia en las dunas costeras del centro de Veracruz. Madera y Bosques 15(3):21-44.

Phillips, J.M. and D.S. Hayman. 1970. Improved procedures for clearing roots and staining parasitic and vesicular-arbuscular mycorrhizal fungi for rapid assessment of infection.

Transactions of the British Mycological Society 55(1):158-161.

Porcel, R., R. Aroca and J.M. Ruiz-Lozano. 2012. Salinity stress alleviation using arbuscular mycorrhizal fungi. A review. Agronomy for Sustainable Development 32(1):181-200

Prasad, R., S. Kamal, P.K. Sharma, R. Oelmüller and A. Varma. 2013. Root endophyte Piriformospora indica DSM 11827 alters plant morphology, enhances biomass and antioxidant activity of medicinal plant Bacopa monniera. Journal of Basic Microbiology 53(12):1016-1024.

Pringle, E.G., R.I. Adams, E. Broadbent, P.E. Busby, C.I. Donatti, E.L. Kurten, K. Renton and R. Dirzo. 2011. Distinct leaf-trait syndromes of evergreen and deciduous trees in a seasonally dry tropical forest. Biotropica 43(3):299-308.

Ramos-Martínez, E.M., A.C. Herrera-Ramírez, J.A. Badillo-Corona, C. Garibay-Orijel, N. González-Rábade and M.C. Oliver-Salvador. 2012. Isolation of cDNA from Jacaratia mexicana encoding a Mexican-like cysteine protease gene. Gene 502(1):60-68.

SARH (Secretaría de Agricultura y Recursos Hidráulicos). 1978. Interpretación agronómica de datos de análisis químicos y físicos de suelos y plantas. SARH, México. 38 p.
Sharma, A. and S. Yadav. 2013. Vesicular arbuscular mycorrhizal fungi associated with rhizosphere of Hordeum vulgare L. in Sikar district. International Journal of Food, Agriculture and Veterinary Sciences 3(1):49-53.

Sudova, R. 2009. Different growth response of five co-existing stoloniferous plant species to inoculation with native arbuscular mycorrhizal fungi. Plant Ecology 204(1):135143.

Tian, Y.H., Y.B. Lei, Y.L. Zheng and Z.Q. Cai. 2013. Synergistic effect of colonization with arbuscular mycorrhizal fungi improves growth and drought tolerance of Plukenetia volubilis seedlings. Acta Physiologiae Plantarum 35(3):687-696.

Trejo, I. and R. Dirzo. 2000. Deforestation of seasonally dry tropical forest: a national and local analysis in Mexico. Biological Conservation 94(2):133-142.

Watts-Williams, S.J. and T.R. Cavagnaro. 2014. Nutrient interactions and arbuscular mycorrhizas: a meta-analysis of a mycorrhiza-defective mutant and wild-type tomato genotype pair. Plant and Soil 384(1-2):79-92.

Wilson, B.A.L., G.J. Ash and J.D.I. Harper. 2012. Arbuscular mycorrhizal fungi improve the growth and nodulation of the annual legume messina (Melilotus siculus) under saline and non-saline conditions. Crop and Pasture Science 63(2):164-178.

Zulueta R., R. 2003. Eficiencia de morfoespecies de hongos formadores de micorriza arbuscular aislados en la rizósfera de Jacaratia mexicana A. DC. para promover la absorción de fósforo. Dissertation, Universidad de Colima, Campus Tecomán, Colima, México. 211p.

Zulueta R., R., L. Varela, E.S. Aguilar, A.D. Trejo and L.C. Lara. 2010. Estatus micorrízico de Jacaratia mexicana y hongos formadores de micorriza arbuscular presentes en selvas bajas caducifolias del Golfo de México. Revista Mexicana de Micología 31:37-44.

Manuscript received on April $11^{\text {th }} 2014$.

Accepted on September $14^{\text {th }} 2015$.

This paper must be cited as:

Zulueta-Rodriguez, R., L.G. Hernández-Montiel, B. Murillo-Amador, M. Cordoba-Matson, L. Lara and I. Alemán C. 2015. Survival and growth of Jacaratia mexicana seedlings inoculated with arbuscular mycorrhizal fungi in a tropical dry forest. Madera y Bosques 21(3):161-167. 